\title{
'Saints without God'
}

\section{Camus's poetics of secular faith}

\author{
Grace Whistler
}

\begin{abstract}
This article addresses Camus's response to Christianity and the problem of suffering in the context of the early twentieth century. Owing to his association with the existentialist movement, it is often assumed that Camus, like many other French intellectuals of the period, rejected Christianity altogether. For this reason, his sympathy with Christian thought is overlooked, and it seems altogether bizarre that some theologians even claimed Camus to be a convert. Among these wildly conflicting claims, Camus's philosophical response to Christianity has become somewhat muddied; in this article I attempt to rectify this. I argue that Camus's entire philosophy is underpinned by his response to Christianity, and that he wanted to re-establish the position of morality in the face of the problem of suffering. I thus demonstrate how his writings manifest this struggle to achieve this goal, in what I refer to as Camus's 'poetics of secular faith'. Camus once claimed, 'I do not believe in God and I am not an atheist'. This article aims to elucidate just what is meant by a statement like this, as well as to catalogue and analyse Camus's innovative attempts at reconciling spirituality and suffering through philosophical literature.
\end{abstract}

\section{Introduction}

'In short,'Tarrou said simply, 'what interests me is to know how one becomes a saint.'

'But you don't believe in God.'

'Precisely. Can one become a saint without God: that is the only concrete question that I know today.' (Albert Camus, The Plague)

The magnitude of suffering experienced and witnessed in the first half of the twentieth century understandably led many people to re-evaluate their moral and spiritual position in the world, and consequently their faith also. No doubt for some, faith in God's divine wisdom was sufficient consolation, but many others rejected religion altogether, unable to accept that any theodicy could justify the immense pain and chaos around them. The art that the world wars inspired naturally embodies the whole spectrum of spiritual responses to suffering and doubt, from the liturgy of T. S. Eliot's 'Ash-Wednesday' all the way to the desolation of Anselm Kiefer's
'Black Flakes', and everything in between. What is of interest to this article, however, is not to be found at either extreme, but somewhere in the middle. Albert Camus, who was born in I9I 3 in predominately Catholic French-Algeria, lost his father in the First World War, and was an active member of the French Resistance, is an artist who was perfectly situated to feel the full force of this spiritual upheaval, and naturally this is manifested in his writings. In this article, I examine what I refer to as Camus's 'poetics of secular faith'. Camus wanted to re-establish the position of morality in the face of the problem of suffering, and his writings manifest this struggle to do so: behind much of his work lies the implicit question of whether this is possible without religion - as Tarrou put it in The Plague ( 1947), 'Can one become a saint without God'? (Camus 2002: I96). Camus once claimed, 'I do not believe in God and I am not an atheist' (Camus 2008: I I2, italics in the original). This article aims to elucidate just what is meant by a statement like this, and thus this article 
catalogues and analyses Camus's innovative attempts at reconciling morality and suffering through literature. While there is evidence of such attempts throughout his works, this essay will lay a particular focus on The Fall (1956), because this work demonstrates more fully than any other, the troubled, conflicted nature of reconciling morality with a godless universe.

So multifaceted was Camus's engagement with Christian thought that he is construed in Christian scholarship as everything from an avid atheist to a 'crypto-Christian'. I will therefore begin by unpacking some of these claims, and attempting to give a firm account of Camus's complex stance with regard to Christianity, making reference to both his philosophical works and the life that informed them (chs. 2-3). Following on from this, I shall begin my investigation of Camus's poetics of secular faith by looking at how he approaches theological and moral problems throughout his creative works - not only his criticisms, but also his longing for spiritual coherence (chs. 4-5). The subsequent section (ch. 6) will take The Fall as an extended case study for Camus's poetics of secular faith, as not only is this work particularly rich in Christian imagery, it also epitomises the spiritual conflict of mid-twentieth-century art.

\section{Camus the Christian?}

Albert Camus grew up in French Algeria in the early twentieth century, in the poor, working-class district of Belcourt, Algiers. While Catholicism was an important part of French society, the poorer classes only really observed religion as a formality, the grandeur of the church and its teachings seeming so very far from the mundane struggles of everyday life. In such an environment, Christianity represented little more to the Camus family than the ceremonial pomp of special occasions, and thus the moral and metaphysical aspects of religion took a while to seem relevant to the young Albert, despite his being confirmed in a local church, and having received holy communion (Todd I 996: 33). But in spite of (and perhaps precisely because of) the indifference to religion in which Camus was raised, as a young adult he became fascinated with early Christian thought, the distance from religion that his upbringing entailed allowing him to approach the philosophical side of Christianity, and evaluate it from the outside. This early interest in Christianity as philosophy inspired him to write his dissertation on Plotinus and Saint Augustine for the Diplôme d'études superieures, which he submitted to the University of Algiers in I 936 (Camus 2017: I). Camus continued to engage with Christian thought throughout the entirety of his career, the formulation of his own philosophy being in many ways a response to it.

Of course, Camus's concern with religion comes not from a place of belief, but rather from a preoccupation with human finitude, and a yearning for meaning and coherence in the face of suffering and death. As Roger Quillot put it, 'Camus was at once both a stranger to the religious spirit, but also profoundly moved by metaphysical anxiety' (Camus 20 I 7: 6). Nevertheless, his engagement with Christian thought is so extensive that interpretations of his stance vary tremendously. Despite being a self-professed agnostic, many writers continue to refer to 'Camus's atheism' (e.g. Blackburn 201 I: 3 I 5), while one critic, who refers to Camus as 'the lay saint', claims that while Camus was 'profoundly opposed to all Christianity stands for' (Peyre I 960: 23) he 'found himself posthumously serving as a theme for many sermons' (ibid. 20). Others have called him 'a religious thinker' and 'a religious moral philosopher' (Hanna I956: 224), or suggested that 'Camus's apparently anti-religious thought' is marked as 'secretly religious' by the very fact he considers death to be a problem at all - apparently this proves that he 'works within the essentially religious apprehension 
that life, if it is to have meaning, must in some way be extended' (Wood I999: 93).

These supposed 'subterranean theological residues at work in Camus's own corpus' (Cristaudo 20I I: I 52), at the extreme, have even inspired several bizarre claims (for which there appears to be no real evidence) that Camus in fact converted to Christianity in secret. While Jean Sarrochi (a sometime respected Camus scholar) called him a 'crypto-Christian' (Gaetani 2017: 5I), perhaps the strangest of all comes from Protestant Minister Howard Mumma, who claims to have befriended and personally converted Camus. In 2000, Mumma wrote a book entitled Albert Camus and the Minister, which claimed that Camus, whilst living in Paris, made a habit of attending the American church to listen to the organist, Marcel Dupré. According to Mumma, Camus was captivated by Mumma's sermons, and the two men became friends. Mumma wrote that Camus had never really read the Bible before (despite what we know of his fascination with Christian theology), until Mumma made him the present of a French translation. Until then, Camus had apparently never thought of reading the Bible in terms of allegory or symbolism, or the subtle relationship between historical fact and spiritual belief that the text encompasses (Cristaudo 20II: I46). While there is no evidence for the veracity of this story (and indeed the idea that Camus, an author so skilled in allegorical writing, had only previously considered literal interpretations of the Bible seems preposterous), it would be risky to dismiss this story as the wishful imagination of an old evangelist without venturing a response. If the entirety of Camus's thought was simply a journey towards conversion, this would seriously undermine his entire philosophy, as Camus strove towards a moral philosophy that was not founded on religion, and such a change of heart would relegate his entire œuvre to a series of stepping stones. Gaetani puts it rather more harshly, saying, 'si
Camus tombe, sa philosophie tombe avec lui' ('if Camus falls, his philosophy falls with him': Gaetani 2017: 60). Rather than dismiss this fanciful story as irrelevant, then, it would instead be prudent to investigate why a Christian minister would even want Camus on their side.

\section{3. 'Dialogue croyant-incroyant'}

Of course, most believers will attest that faith is not something constant and reassuring, despite what some atheists might assume. Believers experience times of doubt and uncertainty, and in fact these incidents are a necessary part of faith; even non-religious philosophers can identify with the need to question and investigate our assumptions in order to formulate better theories, and thus something resembling certainty. A philosopher like Camus, non-Christian though he may have been, nevertheless spent a great deal of his career tackling the challenges of Christianity, and saw the value in dialogue between believers and non-believers (in French, 'un dialogue croyant-incroyant': Camus I 950 : 2 I 2), so it is easy to understand why Christians themselves would find engaging with his works a fruitful pursuit. In fact, there are undoubtedly several key areas of Camus's philosophy which respond directly to Christian thought; these include (but perhaps are not limited to) the faith/reason dichotomy, suffering, transcendence and of course morality itself. Before demonstrating Camus's creative approach to such matters, it would be prudent to outline his philosophical responses. The most famous of Camus's philosophical concepts is of course the absurd, which he explains in The Myth of Sisyphus. The absurd, for Camus, signifies the incongruity between the human desire for meaning and order, and the chaos and indifference of the universe. Camus writes that 'The absurd is sin without God' (Camus 2005: 40), and by this he means that like original sin, humans are born with this curse: it is through no fault of 
our own, but we are condemned to strive for meaning in this finite existence. As James Wood puts it, the absurd 'is the sentence passed on us by life' (Wood r 999: 94). This understanding of humanity's place in the universe is something that acts as a foundation for all of Camus's philosophy, and it is necessary to keep it in mind when considering his responses to Christianity.

In an insightful article, Daniel Berthold points out that the philosophies of Camus and Kierkegaard are in many ways more similar than they might at first appear (Berthold 2013: I3750). While Kierkegaard is very much a Christian philosopher, the picture of faith he presents is by no means one of quiet contentment, it is one of painful struggles in the face of obscurity and suffering (Kierkegaard I 974). Kierkegaard's concept of anxiety is also extremely close to Camus's concept of absurdity; both illustrate the profound sense of isolation the human experiences facing our place in the universe. Camus recognises Kierkegaard's awareness of the absurd, claiming that '[Kierkegaard] does more than discover the absurd, he lives it' (Camus 2005: 24), but despite this acknowledgment, he was nevertheless critical of his faith, bracketing him among those who commit 'philosophical suicide' (ibid. 35 ). Interestingly, Camus seems to base this reading of Kierkegaard largely on that of Leo Chestov, a religious thinker who similarly stood outside organised religion (Chestov was Jewish, though he did not attend worship and predominantly wrote on Christian philosophy) - but along with Kierkegaard, Camus sees Chestov as a believer who is nevertheless sensible of the absurd (ibid. 32-3). Thus, Camus certainly seems to have understood the struggle at the heart of faith, writing, 'I have the impression that faith is not so much a peace as a tragic hope' (Camus I950: 225). What is often overlooked is the reverse effect, which is nevertheless true: Camus's work exhibits a definite sense of faithfulness. Camus's faith, however, is not in God, but in the other - in humanity - despite the doubt and suffering he saw all around him. Camus's rejection of pure reason is a tragic hope for humanity and, as Wood put it, 'it is within this tradition of unstable belief that his thinking breathes its unbelief' (Wood r 999: 89).

While Camus's master's dissertation is neither his most mature nor his most developed response to Christianity, it does illustrate more clearly than anywhere else the kind of Christianity that he admired most. He writes, 'The dialogue of Faith and Reason is staged for the first time in plain light by Saint Augustine ... Reason here becomes more supple. It is illuminated by the light of Faith ... It is not about God that you must believe, but in God' (Camus 2017: 8I) Camus, being interested in Christianity as philosophy, wished to blur this line between faith and reason. As such, the convergence between Greek and Christian thought that Camus describes in this text is perhaps more illuminating in terms of Camus's own thought than in the history of ideas - he wrote:

Neoplatonism is a perpetual effort to reconcile contradictory notion ... Mystical Reason, sensible Intelligence; immanent and transcendent God: the oppositions abound. They all mark however a constant balance between the sensible and the intellectual, the religious aspect of the principles and their explanatory power. In this dialogue at the heart of Reason, truth can only express itself in images ... pouring the intelligible into a sensible form, returning to intuition that which belonged to Reason.

(Camus 201 7: 68)

Here and elsewhere many of the claims he makes about Plotinus and Augustine could just as easily be said of Camus himself: he was without a doubt 'Greek in his need for coherence; Christian in worries and in his sensibility' (Camus 2017: 72). When he writes that 'Plotinus describes the intellect in a sensual fashion. His reason is living, material, and 
moving like a mixture of water and light' (ibid. 52 ), the style here is straight out of Camus's own lyrical essays, a pagan mixture of carnality and mysticism. Camus describes what he sees as the Christian 'disdain for speculation', writing 'It is to the children that the Kingdom of God is promised, but also to the wise people who have known to despoil their knowledge in order to understand the truth of the heart' (ibid. 2 r). While this would ordinarily seem like a harsh criticism coming from a philosopher, we know that Camus believed that reason is not the sole key to philosophical truth - we must feel before we know. This is the kind of secular faith to which he aspires, which is why 'he proceeded less by purely abstract analysis than by personal engagement with problems that arose in the course of his life' (Royal 20I4: 27-8).

For the young Camus, another of the things that was so powerful about Christianity was its depiction of suffering and death - something which we all must face, according to him, on our quest of an authentic life in the face of the absurd. As Roger Quilliot put it, Camus 'has a Christian fascination with the death which triumphs over the flesh' (Camus 201 7: 8). In his dissertation on early Christian thought (several years before he wrote The Myth of Sisyphus), he writes,

true Christians are those who realize this triumph of the martyred flesh. Jesus being man, the whole stress had been put on his death: physically, one cannot go through something more horrible. It is upon ... the torn-up hands and cracked joints, that one should reflect in order to imagine the terrifying image of torture that Christianity established in this symbol. (Camus 20I7: I8-I9)

He takes this contemplation of suffering to be central to Christian thought. For example, he recounts the story of a fourth-century bishop who predicts an impending apocalypse. According to Camus, the generation of Christians who believed in this prophecy represent 'a unique example of a collective experience of death'. He argues that 'to realize the idea of our death gives us a new sense of our life' (Camus 2017: I 8) - this is a claim which is at the heart of his philosophy, and it is therefore clear that Camus would like to replicate this collective experience of death, in order for us to appreciate the gift of life while we still possess it.

But suffering does not only signify the catalyst for authenticity - it is also central to Camus's rejection of transcendence. While, according to Camus, contemplation of suffering and death is precisely what makes humans wish for an afterlife (Camus 2005: 32), it is also the reason we must reject this fantasy - we must never be reconciled to suffering, as to legitimise it would be unjust. The idea that an omnipotent God would allow the existence of so much suffering, therefore, is unacceptable to Camus, and entails what he refers to as 'metaphysical injustice' (Camus 20oob: 29-3I). In a speech entitled 'The unbeliever and the Christians' (Camus I950: 212), which was addressed to a congregation at a Dominican monastery, Camus said, 'I share with you the same horror of evil. But I do not share your hope, and I continue to struggle against this universe where children suffer and die' (Camus I950: 213). This is exemplary of Camus's approach to the problem of suffering. Not only does he acknowledge the Christian moral response to suffering, he also suggests that for him, there could never be a sufficient theodicy. He considers human life to be sacred, and therefore the only solution is to fight against cruelty. From a theistic perspective, one might attribute meaning to the suffering itself, but from an agnostic perspective it would make more sense to accept that life isn't fair, and in fact the existence of God can feel irrelevant when we are truly touched by the suffering of the other. There is no solution to the problem of suffering, and thus this is agnosticism chosen on ethical grounds. 
It is for this reason that Camus also rejects the legitimacy of political violence. If we think it just to commit murder in the name of an ideal (no matter how lofty), we believe that the ideal is somehow transcendent to human life. For Camus, the end never justifies the means morality resides in every action, never a future goal which justifies immorality (Camus 20oob: I35). Truly virtuous motives therefore could never permit violence in the name of an ideal - nothing is worth causing human suffering. Camus, above all then, believed in the value of human life. He wanted to demonstrate the value of morality in a godless universe, and thus he had a 'yearning for a non-Christian concept of the sacred' (Rathbone 20I7: I2I). Unlike the existentialists, who considered the lack of divine authority in the universe as a licence to act freely, from the very beginning Camus rejected the idea of radical freedom. In The Myth of Sisyphus, he wrote, 'The absurd does not liberate, it binds. It does not authorise all actions. Everything is permitted does not mean that nothing is forbidden' (Camus 2005: 65). While he does not develop his moral philosophy fully until later in his career, it is clear from very early on that the lack of a guiding power should not mean the lack of morality. But for Camus, even the idea of a moral theory is corruptible. He jotted in a notebook, 'I have abandoned the moral point of view. Morals lead to abstraction and to injustice' (Camus 2008: 246). By this Camus means that the delineation of rules by necessity marks out exceptions. As Wayne Cristaudo put it, Camus 'shares a deep affinity with the traditional Christian rejection of the idea of salvation through morality, and for much the same reason - that the concrete requirements of love cannot be compressed into a moral formulation' (Cristaudo 20 I r: I47). The kind of morality Camus wished for, then, was more holistic than this - something in fact much closer to the Christian ideal - Camus's ideal moral philosophy is one of love and understanding.
The unifying theme of Camus's third cycle of philosophy was to be, as he put it, 'love' (Royal 20I4: 25). As he died before its completion, and left behind only a few vague, hand-written notes, we can hardly guess how his moral philosophy would have been developed in these works. From what he published in the years before, however, we can speculate on the role he envisaged the concept of love playing in moral philosophy. Rowan Williams, a theologian and ex-archbishop of Canterbury, wrote that 'At the heart of the desperate suffering there is in the world, suffering we can do nothing to resolve or remove for good, there is an indestructible energy for love' (Williams 2007: 10). This is the essence of both Christian and Camusian ethics. Indeed, on many occasions, Camus spoke of love with regard to ethics. In Combat, the French Resistance newspaper that he wrote for and edited, he wrote, 'Humanists have much in common with Christians: [Christians] are taught to love their neighbour. Yet others who do not share their faith may yet hope to arrive at the same goal' (Camus 2006a: 32). In his notebooks, he jotted down numerous notes about love, many harking back to a Christian ideal. He wrote, 'Whoever gives nothing has nothing. The great misfortune is not to be unloved, but not to love' (Camus 2008: 39), and 'Recognize the need for enemies. Love that they exist. Recover the greatest strength, not to dominate but to give' (ibid. 204). We may speculate, therefore, that Camus's ethics would have continued embody this focus on love as a kind of human solidarity, not abstracting from life, or upholding theoretical ideals, but responding to the other with love and compassion.

\section{Faith in the world}

Having seen Camus's conceptual responses to Christianity on a number of themes, it is now time to look at his creative responses, that is, the poetics of Camus's secular faith. I suggest that there are two distinct types of secular faith 
which are manifest in Camus's works, specifically faith in the world and faith in humanity. Camus's earlier works are most characterised by the representation of this faith in the world - a rejection of vertical transcendence in favour of horizontal. Conversely, in response to suffering witnessed in the Second World War, his later works are predominantly characterised in his faith in humanity, and the search for a firm moral ground which circumvents abstraction. As we will see, each of these categories is replete with Christian imagery. As one critic puts it, 'Camus inverts all religious categories, in the process converting them out of their baleful literalism and into the metaphorical'(Wood I999: 94) - thus Camus creates a symbolic, poetic language perfectly suited to the problem of suffering in the twentieth century.

When Camus wrote in the preface to the English edition of The Outsider that Meursault is 'the only Christ we deserve' (Camus 20ooa: II9), this contentious comment reflects his subversive approach to religious imagery. Meursault commits murder - a very un-Christlike act indeed - so Camus's claim no doubt seems improbable, if not scandalous. But Camus was, as one critic put it, 'drawn to the figure of Jesus Christ, because of Jesus' humanity, his humility, his suffering and his compassion for the suffering of others' (Blackburn 2OII: 322 ), and while it would be far-fetched to apply such a definition to Meursault, on further examination it does become clear that he represents a sort of inverted Christ, a misunderstood individual who is put to death by the masses. As Henry Patrick writes, 'He is offered up as a tribal sacrificial victim, not to placate the whims of a revered god, but to insure the validity of the social structure ... Neither attempts to save his life, for each knows that, by doing so, he would lose the validity of that life, its authenticity and its redeeming quality that are only sustained if they are maintained to the end' (Patrick I 975: I62). Thus he is a martyr in a godless universe, which is characterised subtly throughout the novel, as when, on the day of Meursault's trail, his friend Emmanuel fails to present himself in court to give evidence. Emmanuel means 'God is with us' in Hebrew, a name which, at the hour of Meursault's persecution, echoes not only, as Arthur Scherr writes, an 'existential "absent God"' (Scherr 2009: I 97), but also the God whom Christ beseeches from the cross, 'My God, my God, why hast thou forsaken me?'

There are numerous other subtle moments of allusion to the figure of Christ - Meursault is even at one point depicted with a halo; he tells us, 'The chaplain looked at me almost sadly. By now I had my back right up against the wall and my forehead was bathed in light' (Camus 200oa: I 4 ). It is also evident in his non-judgemental acceptance of Raymond's friendship, a violently sinful man whom he will ultimately sacrifice his life for. Raymond asks whether they are copains, approximately equivalent to 'mates' in English, with its literal origins in the Latin 'with + bread', that is sharers of bread (the English 'companion' originating from the same etymological root). Meursault and Raymond are irrevocably bonded by a breaking of bread, as the evening on which they dine together is when Meursault is passively coerced into Raymond's grubby affairs, which eventually lead to his demise. The blood sausage and wine upon which they sup are 'a caricature of the wine and bread that are Christ's body and blood in the Mass and at the Last Supper' (Scherr 2009: 194) - at this Black Mass, it is Meursault who betrays himself. This scene also echoes the temptation of Christ (in Matt. 4:I-II and Luke 4:I-I3) (Scherr 2009: I 94-5), in which hunger is a corrupting force, but of course Meursault succumbs where Christ doesn't. Meursault is martyred on Raymond's account, as his violent dispute would no doubt have continued if Meursault had not stepped in. $\mathrm{He}$ is also the sacrificial lamb of societal propriety; in his unflinching honesty he is willing to die for authenticity. 
But Camus's symbolic treatment of Meursault as a Christ figure is just one element of the novel's response to Christianity. The mixture of innocence and culpability that Meursault represents, as well as his meaningless martyrdom, are both somewhat superficial compared to the philosophical movements made behind these features, which are far too often overlooked. Right at the end of the novel, whilst awaiting execution, there is a passage of Meursault's story which most truthfully represents Camus's own philosophical stance in the novel. Meursault, upon contemplating his imminent death, is transfigured. He does not look to a higher power to save him from his fate, however, like so many literary deathbed conversions. On the contrary, he has a kind of secular epiphany, a moment of communion with the world:

I woke up with the stars shining on my face. Sounds of the countryside wafting in. The night air was cooling my temples with the smell of earth and salt. The wondrous peace of this sleeping summer flooded into me. At that point, on the verge of daybreak, there was a scream of sirens. They were announcing a departure to a world towards which I would now be forever indifferent. For the first time in a very long time I thought of mother. I felt that I understood why at the end of her life she'd taken a 'fiancé' and why she'd pretended to start again. There at the home, where lives faded away, there too the evenings were a kind of melancholy truce. So close to death, mother must have felt liberated and ready to live her life again. No one, no one at all had any right to cry over her. And I too felt ready to live my life again. As if the great outburst of anger had purged all my ills, killed all my hopes, I looked up at the mass of signs and stars in the night sky and I laid myself open for the first time to the benign indifference of the world. (Camus 2000a: I I7)
Here Meursault recognises the 'benign indifference' of the universe that he will become part of very soon, as his concerns do not transcend death. This does not bring him despair, however, as life from this moment, so close to death, seems all the more beautiful and sacred. Meursault's understanding here even leads him to empathise with his mother, his recently discovered immanence being something they, and indeed all of us, have in common.

The contemplation of immanence that Meursault is swept away by in this final scene is something that can be found throughout the works of Camus - as I mentioned earlier in this section, they are most central in his early works, where they illustrate a kind of horizontal transcendence. Camus spent his youth in northern Algeria, with its breath-taking (and to this day) unspoilt Mediterranean landscapes, and he clearly experienced an acute sense of communion with the world. He wrote in Summer in Algiers:

Unity expresses itself here in terms of sea and sky. The heart senses it through a certain taste of the flesh that constitutes its bitterness and greatness. I am learning that there is no superhuman happiness, no eternity outside the curve of the days ... Not that we should behave as beasts, but I can see no point in the happiness of angels. All I know is that this sky will last longer than I shall. And what can I call eternity except what will continue after my death? What I am expressing here is not the creature's complacency about his condition. It is something quite different. It is not always easy to be a man, even less to be a man who is pure. But to be pure means to rediscover that country of the soul where one's kinship with the world can be felt, where the throbbing of one's blood mingles with the violent pulsations of the afternoon sun. (Camus I 970: 90) 
The kind of transcendence that Camus depicts does not appeal to anything outside this world, it appeals precisely to this world - as something powerful, beautiful and incomprehensible, that will outlive us, but that we are part of, and will continue to be after we are dead; as David Rathbone writes, 'His concept of transcendence is explicitly this-worldly, and inseparable from a kind of hyper-immanence (Rathbone 2017: I 26-7). This horizontal transcendence is therefore somewhat pantheistic, as all the spiritual feeling and profundity of emotion that humanity experiences is part of our physical world. As Camus wrote in A Happy Death (I97 I), 'the body has a soul in which the soul has no part' (Camus 20r 3 a: 70).

But the life of the physical is as mundane as it is profound; it consists in the everyday, even if we are sometimes able, philosophically speaking, to look behind the curtain. As Claire in A Happy Death says, 'on good days, if you trust life, life has to answer you' (Camus 20r 3a: 73). All we can do, as part of this world, is to trust in it, to have faith in the vitality which belongs to it, and to us. As Rathbone put it, 'transcendence conceived by Camus [is] temporary, pure, and strictly mundane' (Rathbone 20I7: I3I). This relationship between profoundly spiritual feeling, and the mundane physicality of matter we are part of, is so elusive that indeed the poetics we see in Camus is the only way to speak of a faith in it. Rathbone again writes,

It can only be evoked with symbols, for life must be transformed from absurdity into meaningfulness by being taken as itself symbolic of the indestructibility of life itself. This is not a representation of an other-worldly eternal or immortal life, but an appreciation that the fleeting and fragile lives of mortals can themselves come to symbolise the inseparable and everlasting mixture of vitality and mortality that is the reality of all life in this world. (Rathbone 201 7: I36)
Camus thus sees the rejection of vertical transcendence as a return to something much older, which predates Christianity, almost a corruption of horizontal transcendence, the kind of pagan communion with the world which celebrates the sacredness of life itself. Nevertheless, it is undeniable that this rejection is very much brought into being by his own experience of the events of the twentieth century, and the beginnings of an ethical element to this theory might have been present in 1942 when The Outsider was published, but the following decade crystallised the urgency of such a venture for Camus, as can be seen in the development of his poetics throughout the later creative works.

\section{Faith in humanity}

As has become abundantly clear, Camus's brand of agnosticism by no means renders life meaningless. What is also becoming more salient, too, is that Camus derives his ethics precisely from the fact that this life is all there is, as the suffering in this life becomes more tragic without the mitigating power of transcendence. It is therefore in contemplation of the suffering of the twentieth century that Camus introduces to his writing a welcome and resounding faith in humanity. The philosophical concept which Camus utilised to expound this type of faith is 'revolt', as he formulates in The Rebel (Camus 200ob: $5 \mathrm{I}$ ), referring to a kind of human solidarity that we have a duty to acknowledge in this brief existence. Alongside this seminal philosophical text, he also develops a poetics of revolt in The Plague, an ethical fable which represents the need to struggle in the name of Other, whether that be against disease or totalitarianism. Throughout this novel there are countless questions and answers directed at Christian thought, all within this ethical framework. Dialogues between the narrator, Doctor Rieux, and the priest, Father Paneloux, are a key area in which these ideas are developed. Paneloux's responses to the suffering 
of the plague is the driving force behind many of these conversations: early on in the novel he is able to dismiss the plague as an act of God, a warning to sinners to change their ways or be smote too, but as he comes to witness the suffering of innocents first hand he is thrown into spiritual turmoil. Surely we must trust the divine wisdom and love of God in these trying times? Rieux rejects this stance absolutely, telling him, 'I have a different notion of love; and to the day I die I shall refuse to love this creation in which children are tortured' (Camus 2002: I69). Paneloux adopts the rhetoric of fire and brimstone in his sermons, but in reality he cannot accept this suffering either, and just like the telling nomenclature of Emmanuel in The Outsider, he pleads to a seemingly absent God, 'My God, save this child!' (ibid. I 68). Elsewhere in the novel, Tarrou, a fellow combatant of the plague tries to formulate his own poetics of suffering. His search for morality without God is a Quixotic endeavour to become 'A saint without God' (ibid. I 96). For Rieux, the difficulties posed simply by being human in the face of universal suffering is enough, but Tarrou, who realises that the pure and perfect ideal of sainthood is divorced from everyday struggles, believes the task of being human is even more ambitious (ibid. 197).

Of course, Camus believes that the only way for humans to make any progress is to work tirelessly at the paradoxically unavoidable and impossible task of simply being human (as indeed he tells us all the way back in The Myth of Sisyphus), and as well as Rieux, he paints other portraits of the kind of secular saviour we need to move on from the horrors of war and totalitarianism. One such example is d'Arrast, in the short story 'The Growing Stone' from the collection Exile and the Kingdom (Camus 2006b). Set in a remote town in Iguape, Brazil, this is yet another example of Camus's image of a pre-Christian world. While the tribal people of the town do observe Christianity, it is a ritualistic, pagan interpretation which seems so alien to d'Arrast on his arrival, fresh from France. Out of respect and friendship towards one of the townspeople who is unable to perform their (Sisyphean) annual ritual of carrying a boulder through the town to the church, he takes the task upon himself, instead carrying the boulder to the hearth of his friend who is suffering from exhaustion, where he is welcomed and celebrated. In this action, d'Arrast sets a precedent for the humanisation and secularisation of their practices. Thomas Claire writes,

In examining the wealth of Christian imagery in 'La Pierre qui pousse', it is essential to note the distinction between d'Arrast and the Christ of the Christian tradition as seen by Camus: unlike Christ, who became an institutionalized figure preaching salvation through faith in the future, d'Arrast opens the way for the people of Iguape to find fulfilment in their present circumstances by teaching them that man must be directly responsible for his actions. (Claire I 976: 28)

D'Arrast's actions are in honour of human frailty and kinship which eludes social expectation, the solidarity which inspired him to take up his friend's burden also provoking his subversion of religious rites. Camus sees this as the only possible way forward for any kind of humanist morality, as is summed up by the following sentiment taken from the aptly named The First Man. The protagonist, Jacques Cormery, loosely based on the young Camus himself, considers himself to be "with no past, without ethics, without guidance, without religion, but glad to be so and to be in the light' (Camus 20I3b: I 50). After the horrific events of the early to mid-twentieth century, all that is left to do is to start from scratch - not in innocence, like Adam in the Garden of Eden, but in experience and humility. 


\section{The Fall}

While The Fall is perhaps Camus's bleakest novel, it is also the one that is rooted most deeply in Christian imagery - so much so that it would be impossible to examine it comprehensively in this short article. The title obviously alludes to the story of Adam and Eve, and much like that story, The Fall mourns a loss of innocence - but of course it is not the paradise of the garden of Eden that is lost, but the relative bliss of a time before the Holocaust and trench-warfare. The protagonist, Jean-Baptiste Clamence, a selfproclaimed 'Judge-Penitent', confesses his sordid life-story to a stranger in a bar over the course of several evenings, and leads the reader through a nightmarish version of Amsterdam, the city's concentric canals mimicking the circles of hell in Dante's Inferno. Clamence, unlike his creator, has no sense of the sacred, and his stories paint a picture of feigned selflessness, cynicism and cowardice. Nevertheless, this novel is, as Maher writes, 'positively crying out for ... spiritual redemption' (Maher nd). The reader, in the position of a priest hearing confession, is told (for example) of the night that Clamence, the sole witness to a woman's suicide attempt as she jumped from a bridge in Paris, instead of trying to save her simply left the scene without backward glance. Clamence is apparently haunted by this episode and ironically, considering his namesake John the Baptist, Clamence cannot stand the sight of water, and will no longer cross a bridge at night. This sarcastic raconteur cannot escape his own sins, let alone cleanse those of others: he tells us, 'With me, there is no benediction, no absolutions are handed out' (Camus 2006c: 82). The list of such allusions and symbols in the novel goes on.

While there is no room in the current article to thoroughly catalogue the full wealth of religious imagery in The Fall, it is certainly important to try to understand the role that Christianity has in this novel, and Camus's response to the moral questions which arise in the text. Clamence, on the surface, lived a life of virtue. He was a lawyer who specialised in representing vulnerable people (such as widows and orphans), went out of his way to perform good deeds, and was duly successful and celebrated for it. But Clamence is the epitome of a selfish moralist - he does all the right things for all the wrong reasons. When Clamence finally owns up to himself about his duplicitous egotism, he abandons his career and adopts the mysterious title of 'Judge-Penitent', seeking (or so it seems) redemption through the practice of confession. He confesses his mistreatment of women, numerous misdeed and betrayals, and even a bizarre episode in which he adopts the position of 'Pope' of a prisoner of war camp, and legitimises stealing water from a dying prisoner because of his fictitious spiritual importance. But unfortunately for Clamence, where there is no God, there is no divine redemption. Maher writes, 'the existentialists had killed God, yet they offered nothing to replace Him, thus leaving a guilt-ridden man like Jean-Baptiste Clamence with nowhere to turn ... And so he turns to his only alternative, his fellow man' (Maher nd). And so Clamence spends his days in bars, waiting for a sympathetic listener (reader) to come along and share in his spiritual anguish.

While it is true that Clamence has no-one to turn to but his fellow man, it is not the case that The Fall 'provides no answers, only painful, almost desperate questions', as Maher goes on to suggest (Maher nd). Through Clamence's endless embittered chatter, the desire for a Christ figure is ever present; he asks, 'Who would sleep on the floor for us, my dear sir?' (Camus 2006c: 2 I). The simple humility that Clamence begs for in such a question, however, is nothing miraculous or transcendent - in fact this moving image of self-sacrifice is purely human. This is the kind of gesture that echoes Camus's emphasis on love and solidarity that we have already seen elsewhere, and in fact, as Barry and Paterson 
write, 'Camus seems to be telling us that the key to human community or communion is found in the human Christ who alone was free and willing to 'sleep on the floor for us' (Barry and Paterson I 976: 4I), and thus The Fall'may ... be read as an extended struggle towards dialogue and relation' (ibid. 38). In the world of The Fall, there is no God, no ultimate redemption, and we must live with our guilt - but through recognition of our position in the world, and solidarity with our fellow human beings, we can all take on the role of the human Christ.

\section{Conclusion}

As we have seen, Camus spent a great deal of his career responding to the questions raised by Christianity, particularly focussing on theological responses to suffering. Camus's non-belief is not motivated by nihilism, or even scepticism towards mysticism or concepts of the sacred in fact Camus's creative works demonstrate his understanding and respect for these aspects of Christian thought and writing. As John Cruickshank writes, 'What makes Camus so significant, and in many ways representative, a figure of his own generation is the fact that he experienced a religious need in its widest sense yet was unable to accept religious belief' (Cruikshank I967: 324). Camus personally rejects Christianity on the grounds that he can see no reason that suffering could ever be legitimised, but his critique of Christianity is really only aimed at 'phantasmic Christianity, that is, Christianity when it is pathological in its otherworldliness, and either indifferent, masochistic, or destructive to the world' (Cristaudo 20 I I: I 54). Thus he continued to engage with Christian thought, his 'brilliant working at the frontier between belief and unbelief ... and his effort to live honestly and decently despite the ideological horrors of the twentieth century' (Royal 20I4: 26) characterising his creative works, and motivating his choice of Christian symbolism to illustrate moral problems.
In this article I have given a brief account of Camus's poetics of suffering and faith, demonstrating just some of the instances in his creative works when he has used Christianity as a springboard for developing his moral response to the chaos of the early to mid-twentieth century. From secular Christ-figures to prophetic plagues, Camus elaborated his need for a secular faith explicitly through Christian symbolism, thereby demonstrating both his respect for Christian thought and scripture, as well as critiquing the ways in which its morality failed to respond to the suffering around him. As one critic writes, 'The works of Camus ... have asked the right questions and constrained Christians to evolve ever more satisfactory answers to them' (Peyre 1960: 21). Through his rich weaving of Christian imagery and humanist ethics, Camus formulates a kind of faith that he sees as the only way to move forward - faith in the world and in humanity itself. Given the extent to which Camus investigated Christian theology, it is hardly a surprise that Minister Mumma saw his potential as a powerful an ally. After all, what could be more persuasive in the process of conversion than the idea that Camus, who had voiced so many nuanced concerns with Christianity, had finally had his doubts assuaged? Unfortunately for Mumma, Camus's stance on Christianity is too clear to make his story believable - nevertheless, Camus's responses to Christianity should earn him a place in Christian ethics for many years to come.

Grace Whistler is a $\mathrm{PhD}$ candidate at the University of York. Her thesis, entitled 'Between Content and Form: Camus's Literary Ethics', reassess the writings of Albert Camus in relation to current debates at the intersection of ethics and aesthetics. She has published articles in

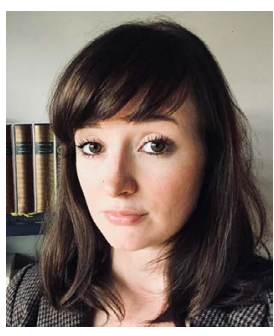
Literature and Theology, the Journal of Camus Studies and the Journal of Life Writing, and is currently working on a chapter for Brill's Companion to Albert Camus. 


\section{References}

Barry, Catherine, and William Paterson, I 976. 'The concepts of community and Christology in Camus' The Fall, Christianity and Literature, 25, pp. 37-42

Berthold, Daniel, 20r 3. 'Kierkegaard and Camus: either/or?', International Journal of Philosophy and Religion, 73, pp. I 37-50

Blackburn, Vivienne, 20 I r. 'Albert Camus: the challenge of the unbeliever', Scottish Journal of Theology, 64(3), pp. 3 I 3-26

Camus, Albert, I950. Actuelles: Chroniques 1944-1948 (Paris, Gallimard)

- 1970. Lyrical and Critical Essays, ed. Philip Thody (New York, Vintage)

-2000a. The Outsider, trans. Joseph Laredo (London, Penguin)

2ooob. The Rebel, trans. Anthony Bower (London, Penguin)

2002. The Plague, trans. Robin Buss

(London, Penguin)

2005. The Myth of Sisyphus, trans. Justin

O'Brien (London, Penguin)

-2006a. Camus at Combat: Writing 1944-1947, ed. Jacqueline Lévi-Valensi (Princeton and Oxford, Princeton University Press)

2006b. Exile and the Kingdom, trans. Carol Cosman (London, Penguin)

-2006c. The Fall, trans. Justin O'Brien (London, Penguin)

2008. Notebooks, Vol. III: 1951-1959, trans. Ryan Bloom (Chicago, Ivan Dee)

_-2or 3a. A Happy Death, trans. Richard Howard (London, Penguin)

-2013b. The First Man, trans. David Hapgood (London, Penguin)

20 1 7. Between Plotinus and Saint Augustine, trans. David Rathbone <http://www. academia.edu/I I35088 I/Albert_Camus_ Between_Plotinus_and_Saint_Augustine_> (accessed 30.3.2018)

Claire, Thomas, I 976. 'Landscape and religious imagery in Camus' "La Pierre Que Pousse", Studies in Short Fiction, I 3(3), pp. 32 I-30

Cristaudo, Wayne, 201 I. 'The Johannine Christianity of Albert Camus', Culture, Theory and Critique, 52(2-3), pp. I 45-6 I

Cruickshank, John, I967. 'Albert Camus: sainthood without god', Mansions of the Spirit: Essays in Literature and Religion, ed. George

A. Panichas (New York, Hawthorn), pp. 3I $3-24$

Gaetani, Giovanni, 2017. "'Les avocats de
Camus" : faire le point sur les différentes tentatives de christianiser sa vie et sa pensée', Albert Camus: Carte Blanche (Le Pontet, Barthélemy), pp. 4 I-6I

Hanna, Thomas L., I 956. 'Albert Camus and the Christian faith', The Journal of Religion, 36(4), pp. 224-33

Kierkegaard, Søren, 1974. The Sickness unto Death, trans. W. Lowrie (Princeton University Press)

Maher, Jimmy, nd. 'Camus, The Fall, and the question of faith', <http://maher.filfre.net/ writings/camus.htm> (accessed 30.10.20I 7)

Patrick, Henry, I 975. Voltaire and Camus: The Limits of Reason and the Awareness of Absurdity (Banbury, The Voltaire Foundation)

Peyre, Henri, i 960. 'Camus the pagan', Yale French Studies, 25, pp. 20-5

Rathbone, David, 201 7. 'Postscript', Between Plotinus and Saint Augustine by Albert Camus, trans. David Rathbone <http://www. academia.edu/I I 35088I/Albert_Camus_ Between_Plotinus_and_Saint_Augustine_> (accessed 30.3.2018)

Royal, Robert, 201 4. 'Camus: between god and nothing', First Things, I, pp. 25-30

Scherr, Arthur, 2009. 'Meursault's dinner with Raymond: a Christian theme in Albert Camus's L'Etranger', Christianity and Literature, 58(2), pp. I 87-2 Io

Todd, Olivier, I 996. Une Vie (Paris, Gallimard) Williams, Rowan, 2007. Tokens of Trust (London, Canterbury Press)

Wood, James, I 999. 'Camus and twentiethcentury clarity: the sickness unto life', The New Republic, pp. 88-96 